\title{
Statins and prevention of infections: systematic review and meta-analysis of data from large randomised placebo controlled trials
}

\author{
(c) $(1)(9)$ OPEN ACCESS
}

\author{
Hester L van den Hoek graduate student ${ }^{13}$, Willem Jan W Bos internist ${ }^{2}$, Anthonius de Boer professor \\ of pharmacotherapy ${ }^{1}$, Ewoudt M W van de Garde clinical pharmacist and epidemiologist ${ }^{13}$
}

'Division of Pharmacoepidemiology and Clinical Pharmacology, Faculty of Science, Utrecht University, Utrecht, Netherlands; ${ }^{2}$ Department of Internal Medicine, St Antonius Hospital, Nieuwegein, Netherlands; ${ }^{3}$ Department of Clinical Pharmacy, St Antonius Hospital, Koekoekslaan 1, PO Box 2500 , 3430 EM, Nieuwegein, Netherlands

\begin{abstract}
Objective To evaluate whether the potential of statins to lower the risk of infections as published in observational studies is causal.

Design Systematic review and meta-analysis of randomised placebo controlled trials.

Data sources Medline, Embase, and the Cochrane Library.

Study selection Randomised placebo controlled trials of statins (up to 10 March 2011) enrolling a minimum of 100 participants, with follow-up for at least one year.

Data extraction Infection or infection related death.

Results The first study selection yielded 632 trials. After screening of the corresponding abstracts and full text papers, 11 trials totalling 30 947 participants were included. 4655 of the participants (2368 assigned to statins and 2287 assigned to placebo) reported an infection during treatment. Meta-analysis showed no effect of statins on the risk of infections (relative risk $1.00,95 \%$ confidence interval 0.96 to 1.05 ) or on infection related deaths $(0.97,0.83$ to 1.13$)$.
\end{abstract}

Conclusion These findings do not support the hypothesis that statins reduce the risk of infections. Absence of any evidence for a beneficial effect in large placebo controlled trials reduces the likelihood of a causal effect as reported in observational studies.

\section{Introduction}

Statins (hydroxymethyl glutaryl coenzyme A (HMG-CoA) reductase inhibitors), drugs used to lower cholesterol levels, are prescribed frequently and their cardiovascular benefits are widely accepted in medical practice. In addition to cholesterol lowering effects, statins have anti-inflammatory and immunomodulatory properties, so called pleiotropic effects.
Such effects might be beneficial in the management of infections. $^{1-3}$

Whether statins can help to prevent infection is still debated. Since 2006, population based observational studies have reported associations between statins and a reduced risk of infectious outcomes such as pneumonia and sepsis and infection related mortality, with preventive effects up to $76 \%{ }^{4-10}$ However, the possibility of biased estimations of effect, which are inherent in observational studies, cannot be excluded. Recently, some investigators suggested that the protective associations reported in many of these studies could reflect bias from "healthy user" effects - that is, that statin users tend to have less severe comorbidity and better functional status than non-users and are more likely to practise other healthy behaviours. Despite extensive efforts to minimise all types of confounding and other biases, the effects of statins on risk of infection are inconclusive. ${ }^{11} 12$

We hypothesised that if a preventive effect of statins on the risk of infections existed it should be detectable in the data of large placebo controlled trials. Considering the placebo controlled nature of such trials this would mean a true effect. We carried out a systematic review and meta-analysis of placebo controlled trials of statins to evaluate whether the beneficial association between statins and infections published in observational studies is causal.

\section{Methods}

We carried out a systematic review and meta-analysis of published trials according to the preferred reporting items for 
systematic reviews and meta-analyses (PRISMA) guidelines. ${ }^{13}$ A systematic search of Medline in PubMed, Embase, and the Cochrane Library database (the Cochrane central register of controlled trials) for studies reporting an infection as an adverse event or cause of death related to statin use was done from inception to 10 March 2011. To identify further articles we hand searched references and the related citations in PubMed.

We included randomised controlled trials reported in English only. Search terms, MeSH subject headings, and limits were

"hydroxymethylglutaryl-CoA reductase inhibitors",

"anticholesteremic agents", "statin", "simvastatin",

"rosuvastatin", "pravastatin", "atorvastatin”, "fluvastatin",

"cerivastatin", "pitavastatin", "lovastatin", "placebo controlled", and "randomised controlled trial".

\section{Inclusion and exclusion criteria}

All captured publications were screened according to predefined selection criteria. We included all randomised controlled trials with a statin as active treatment and a placebo as comparator. Eligible studies had a follow-up period of at least 12 months, a minimum of 100 participants, and reported on infections or infection related mortality. We excluded duplicate

publications-that is, two or more studies that investigated the same sample.

After the first automated query in the databases, we used a three step process for screening. Firstly, we screened the abstracts.

Secondly, we screened the remaining publications on the basis of the corresponding full text publication for reports on adverse events and causes of death. Finally, we screened the articles with information on adverse events and mortality for reports on the occurrence of infections or infection related mortality.

Besides the predefined search strategy, one reviewer (HLvdH) considered trials that had been excluded in the final step for not reporting infections as of potential importance when extensive data on other adverse events were available. The principal investigators of these trials were then contacted for supplementary data.

\section{Data extraction}

One reviewer (HLvdH) extracted the data. From each eligible publication data were captured on first author, year of publication, title, journal, study population, primary study outcome, duration of follow-up, number of participants in each group (statin and placebo groups), and type and dose of statin studied. From each included study HLvdH extracted data on the occurrence of infections as adverse events and data on infection related mortality.

\section{Quality and risk of bias assessment}

Using the Cochrane risk of bias tool we screened all captured trials for quality of study design, including randomisation, blinding, withdrawal, and dropouts. ${ }^{14}$ Because we studied unexpected "adverse" events in this systematic review we focused our assessment on quality of reporting adverse events and withdrawal of treatment in both study arms. Withdrawal of treatment was considered to rule out the possibility that differences in denominators may explain differences in calculated infection rates.

\section{Statistical analysis}

Statistical analysis of the dichotomous variables was carried out using relative risk as the summary statistic. We used random effect modelling by DerSimonian-Laird for analysis and reported results in a forest plot with $95 \%$ confidence intervals. The relative risks represented the risk of an adverse event happening during study interval in participants taking a statin compared with those taking a placebo. When possible we carried out subgroup analyses and stratified the results for type of statin, statin dosage, patients' characteristics, and type of infection. A relative risk of less than 1 would favour the statin treated population; we considered the point estimate of the relative risk to be significant at the $\mathrm{P}<0.05$ level if the confidence interval did not include the value 1 . Heterogeneity was analysed using the Cochran Q test $\left(\chi^{2}\right)$ and $\mathrm{I}^{2}$ statistics as a complement to the $\mathrm{Q}$ test. ${ }^{15}{ }^{16} \mathrm{I}^{2}$ is the proportion of total variation observed between the trials attributable to differences between trials rather than to sampling error (chance), with values less than $30 \%$ representing low variation, less than $60 \%$ moderate variation, and greater than $60 \%$ high variation. Analyses were done with PASW Statistics 18.0 for Windows (SPSS). We carried out additional sensitivity analysis to explore the influence of the quality and risk of bias found in the included trials.

\section{Results}

The first database query yielded 607 publications (fig $1 \Downarrow$ ). Another 25 studies were identified by hand searching. After removal of duplicates, the remaining 587 articles were screened on the basis of the title and abstract. Only 135 trials fulfilled the inclusion criteria. These trials were further evaluated for reporting on the incidence of adverse events and mortality. Of the 39 trials reporting adverse events and causes of death, 10 publications had information on infections. Additionally, 13 trials were certified as potentially relevant and the authors were contacted for primary and supplementary information (see web extra). Of these 13 trials, only one study group provided additional information. In total, the final selection comprised 11 trials. Analyses were carried out on these 11 trials.

\section{Baseline characteristics}

Table $1 \Downarrow$ summarises the baseline characteristics of the included trials. The 11 trials randomised 30947 participants: 14103 (45.6\%) received statin therapy and 16844 (54.4\%) received placebo. The average follow-up was 3.3 (range 1-5.1) years. The mean age of the patients was 63 (range 48 to 73 ) years (see web extra).

Of the 11 randomised controlled trials, one was not double blinded (table $2 \Downarrow$ ). Three of the trials stated they were randomised but did not give the specific method of sequence generation, although they did state that investigators and participants were blinded to the process of randomisation. Except for one trial, ${ }^{17}$ study quality was satisfactory overall and the trials were judged to be at low risk of bias (adequate sequence generation or allocation concealment, double blinding, and clear reporting of withdrawal rates and loss to follow-up). All trials were based on intention to treat analysis of long term treatments. The original publications of the trials included in this meta-analysis reported that $1.1-34.6 \%$ of participants assigned to statins had stopped using the drugs by the end of follow-up, similar to the $1.0-44.2 \%$ of participants assigned to placebo.

\section{Occurrence of infections}

Data on infection related adverse events and infection related mortality were retrieved from the original publications, except for the GISSI-heart failure trial ${ }^{21}$ where the authors provided the relevant data on request. In total, 4655 patients experienced an infection during treatment, reported as an adverse event or 
cause of death. Of these patients, 2368 were assigned to statins and 2287 to placebo. Table $3 \Downarrow$ provides details of the individual trials. Most did not report the site of infection.

\section{Statin treatment and outcome events}

In meta-analysis the use of statins was not associated with a decrease in the risk of infection related adverse events compared with placebo (relative risk 1.00, 95\% confidence interval 0.96 to $1.05 ; \mathrm{P}=0.93$, fig $2 \Downarrow$ ). Heterogeneity of the included studies was low $\left(\mathrm{I}^{2}=5.5 \%\right)$. Similarly, statins were not associated with a reduction in the risk of infection related mortality $(0.97,0.83$ to $1.13 ; \mathrm{P}=0.71$, fig $3 \Downarrow$ ). The included studies also showed low heterogeneity $\left(\mathrm{I}^{2}=18.8 \%\right)$. In sensitivity analysis the exclusion of data from the trial lacking double blinding ${ }^{17}$ did not significantly alter the results for infection related mortality $(0.98$, 0.84 to 1.14$)$

\section{Discussion}

In this systematic review and meta-analysis of data from randomised placebo controlled trials of statins, we found no evidence to support the hypothesis that statins decrease the risk of infection. We pooled the data of 30947 participants, giving a relative risk of 1.00 for infections and 0.97 for infection related mortality. Absence of any evidence towards a beneficial effect of statins on risk of infection in large placebo controlled statin trials does not support a causal protective association between statins and infections as reported in observational studies.

\section{Comparison with other studies}

Our results differ from those of most of the observational studies that examined use of statins and risk of infections. Since 2006, observational studies have reported a possible beneficial effect of statins on risk of infection. ${ }^{43}{ }^{44}$ Many such studies showed beneficial effects, but a study by Majumdar et al was the first to introduce the so called healthy user effect as a possible source of bias in these studies. Although these researchers studied the effects of statins on prognosis of infections, their findings that analyses with more thorough adjustment, including for functional status, showed no association might also extend to prevention of infections. ${ }^{11}$ In 2009 a study reported that statin use was not associated with a decreased risk of pneumonia when adjusted for measures of functional or cognitive state. ${ }^{12}$ More recently, statins have been linked to an increased risk of infection after stroke and no evidence of an effect on risk of invasive mould infection. ${ }^{45} 46$

A major methodological difference between these studies and our study may explain the divergent results. Most importantly, and inherent to the study design, observational studies are always at risk of unmeasured confounding. A major strength of our meta-analysis of data from only randomised controlled trials is the absence of such bias. The so called healthy user effect, for example, should be absent when allocation to statin treatment or to placebo is determined by chance. Given that our study showed an effect size of about zero provides evidence that previous findings from observational studies indeed might be biased.

Although it is likely that results from the trials were correct and analyses from observational studies were biased, the reverse scenario is also plausible. Firstly, the reporting of infections was limited and most researchers did not provide additional data on request. Therefore we might have included a non-representative sample of statin trials for infectious outcomes. However, the lack of effect reported in the published trials would be biased only in the unlikely scenario of preferential publication of null findings. Secondly, we cannot rule out the possibility that statins still might be beneficial in some categories of patients. Although our meta-analysis provided no suggestion for a specific subgroup with reduced risk of infection, this might be missed because randomised trials in general include "healthier" people with fewer comorbidities and drugs used concurrently. On the other hand, most of the participants in this meta-analysis had renal disease and diabetes, two known risk factors for infections, and comparable to the type of patients largely present in many of the observational studies showing a large beneficial effect, whereas our study found a null effect. Also, the mean age of the patients in the present meta-analysis did not differ from the available observational studies (63 years $v 63$ years).

In the present study we focused on the effects of statins on risk of infection. We know that a large amount of observational data exists suggesting acute statin effects to improve the prognosis of infection. In our opinion, prevention and treatment effects are both important, but they are clearly different. It is not inconceivable that statins influence the inflammatory response in the acute phase of infection without affecting the overall risk of acquiring infection. According to Clinicaltrials.gov, several randomised clinical trials of statins in the setting of sepsis and pneumonia are currently under way. The findings from these trials will help to answer what statins can add to our shared effort to improve the prognosis of infection.

\section{Strengths and limitations of the study}

Strengths of our study include the effort to minimise confounding and the alternative approach used. Firstly, we carried out a thorough systematic review of all placebo controlled trials of statins for data on the presence of infections. This was followed by a meta-analysis to analyse unbiased statin effects on the risk of acquiring infections. This alternative approach provides a unique chance to explore the heterogeneity among the observational studies on the subject. This approach has also been applied to explore the reporting of statins and their effects on risk of fracture. ${ }^{47}$

Our study also has some limitations. Mainly, of the 632 publications screened only 11 trials reported on the incidence of infections. Therefore we were unable to carry out subgroup analyses for statin dose, type of statin, patients' characteristics, and type of infection. Secondly, we have no information on the validity of the infectious outcomes, as these were not predefined study outcomes. We do, however, feel confident that infections are major events that would be noticed. Furthermore, if validity was impaired we would expect this to be non-differential and not to lead to an inaccurate estimate of the relative risk of infection.

\section{Conclusions and policy implications}

Our systematic review and meta-analysis of data on infectious outcomes in large placebo controlled statin trials did not provide evidence to support the hypothesis that statins decrease the risk of infections. On the basis of previous observational studies, many investigators have called for randomised trials of statins for the prevention of infections. Our finding of an absence of any protective effect shows that results from the observational studies might be biased and that the arguments for setting up such a trial are weakened. Besides this, given our observed effect size of about zero, the sample size and follow-up time required for adequate power to show a difference would be approximately infinite. Furthermore, such a trial could entail 
withholding statin treatment for a long period from people with an indication for such treatment. In our opinion, such a study would be unethical. According to Clinicaltrials.gov, numerous randomised clinical trials with long term use of statins are planned or recruiting patients. A better approach could be to push reporting of infectious outcomes in detail whenever statin trials are undertaken. This would have better prospects for identifying subgroups in whom there may be effects worthy of additional testing in a focused randomised trial.

Contributors: EMWvdG conceived and designed the study. HLvdH acquired the data, carried out the statistical analysis, and drafted the manuscript. HLvdH had full access to all of the data in the study and takes responsibility for the integrity of the data and the accuracy of the data analysis and is the guarantor. All authors were involved in interpretation of results and drafting and revising the manuscript. All authors approved the final submitted version.

Funding: No funding sources had a role in the study design, data collection, data analysis, data interpretation, or writing of the report.

Competing interests: All authors have completed the ICMJE uniform disclosure form at www.icmje.org/coi_disclosure.pdf (available on request from the corresponding author) and declare: no support from any company for the submitted work; WB had relationships with AstraZeneca and Merck/Schering Plough, for participation in the AURORA (A Study to Evaluate the Use of Rosuvastatin in Subjects on Regular Hemodialysis: An Assessment of Survival and Cardiovascular Events) trial and the SHARP (Study of Heart and Renal Protection) trial, respectively, in the previous three years; and no other relationships or activities that could appear to have influenced the submitted work.

Ethical approval: Not required.

Data sharing: No additional data available.

1 Fessler MB, Young SK, Jeyaseelan S, Lieber JG, Arndt PG, Nick JA, et al. A role for hydroxy-methylglutaryl coenzyme a reductase in pulmonary inflammation and host defense. Am J Respir Crit Care Med 2005;171:606-15.

2 Chalmers JD, Short PM, Mandal P, Akram AR, Hill AT. Statins in community acquired pneumonia: evidence from experimental and clinical studies. Respir Med 2010;104:1081-91.

3 Yende S, Milbrandt EB, Kellum JA, Kong L, Delude RL, Weissfeld LA, et al. Understanding the potential role of statins in pneumonia and sepsis. Crit Care Med 2011;39:1871-8.

4 Van de Garde EM, Hak E, Souverein PC, Hoes AW, van den Bosch JM, Leufkens HG. Statin treatment and reduced risk of pneumonia in patients with diabetes. Thorax 2006;61:957-61.

5 Hackam DG, Mamdani M, Li P, Redelmeier DA. Statins and sepsis in patients with cardiovascular disease: a population-based cohort analysis. Lancet 2006;367:413-8.

6 Fernandez R, De Pedro VJ, Artigas A. Statin therapy prior to ICU admission: protection against infection or a severity marker? Intensive Care Med 2006;32:160-4.

7 Gupta R, Plantinga LC, Fink NE, Melamed ML, Coresh J, Fox CS, et al. Statin use and sepsis events [corrected] in patients with chronic kidney disease. JAMA 2007;297:1455-64.

8 Almog Y, Novack V, Eisinger M, Porath A, Novack L, Gilutz H. The effect of statin therapy on infection-related mortality in patients with atherosclerotic diseases. Crit Care Med 2007;35:372-8.

9 Coleman Cl, Lucek DM, Hammond J, White CM. Preoperative statins and infectious complications following cardiac surgery. Curr Med Res Opin 2007;23:1783-90.

10 Schlienger RG, Fedson DS, Jick SS, Jick H, Meier CR. Statins and the risk of pneumonia: a population-based, nested case-control study. Pharmacotherapy 2007;27:325-32.

11 Majumdar SR, McAlister FA, Eurich DT, Padwal RS, Marrie TJ. Statins and outcomes in patients admitted to hospital with community acquired pneumonia: population based prospective cohort study. BMJ 2006;333:999.

12 Dublin S, Jackson ML, Nelson JC, Weiss NS, Larson EB, Jackson LA. Statin use and risk of community acquired pneumonia in older people: population based case-control study. BMJ 2009;338:b2137.

13 Liberati A, Altman DG, Tetzlaff J, Mulrow C, Gotzsche PC, loannidis JP, et al. The PRISMA statement for reporting systematic reviews and meta-analyses of studies that evaluate healthcare interventions: explanation and elaboration. BMJ 2009;339:b2700.

14 Higgins JPT, Altman DG, Sterne JAC. Assessing risk of bias in included studies. In: Higgins JPT, Green S, eds. Cochrane handbook for systematic reviews of interventions Version 5.1.0 (updated March 2011). The Cochrane Collaboration, 2011. Available from www.cochrane-handbook.org.

15 DerSimonian R, Laird N. Meta-analysis in clinical trials. Control Clin Trials 1986;7:177-88.

16 Galbraith RF. A note on graphical presentation of estimated odds ratios from several clinical trials. Stat Med 1988;7:889-94.

17 Stegmayr BG, Brannstrom M, Bucht S, Crougneau V, Dimeny E, Ekspong A, et al. Low-dose atorvastatin in severe chronic kidney disease patients: a randomized, controlled endpoint study. Scand J Urol Nephrol 2005;39:489-97.

18 Fellstrom BC, Jardine AG, Schmieder RE, Holdaas H, Bannister K, Beutler J, et al. Rosuvastatin and cardiovascular events in patients undergoing hemodialysis. $N$ Engl $J$ Med 2009;360:1395-407.
19 Kjekshus J, Apetrei E, Barrios V, Bohm M, Cleland JG, Cornel JH, et al. Rosuvastatin in older patients with systolic heart failure. N Engl J Med 2007:357:2248-61.

20 Amarenco P, Bogousslavsky J, Callahan A 3rd, Goldstein LB, Hennerici M, Rudolph AE, et al. High-dose atorvastatin after stroke or transient ischemic attack. N Engl J Med 2006;355:549-59.

21 GISSI-HF Investigators, Tavazzi L, Maggioni AP, Marchioli R, Barlera S, Franzosi MG, et al. Effect of rosuvastatin in patients with chronic heart failure (the GISSI-HF trial): a randomised, double-blind, placebo-controlled trial Lancet 2008;372:1231-9.

22 Wanner C, Krane V, Marz W, Olschewski M, Mann JF, Ruf G, et al. Atorvastatin in patients with type 2 diabetes mellitus undergoing hemodialysis. N Engl J Med 2005;353:238-48.

23 Holdaas H, Fellstrom B, Cole E, Nyberg G, Olsson AG, Pedersen TR, et al. Long-term cardiac outcomes in renal transplant recipients receiving fluvastatin: the ALERT extension study. Am J Transplant 2005;5:2929-36.

24 Serruys PW, de Feyter P, Macaya C, Kokott N, Puel J, Vrolix M, et al. Fluvastatin for prevention of cardiac events following successful first percutaneous coronary intervention: a randomized controlled trial. JAMA 2002;287:3215-22.

25 Newman CB, Szarek M, Colhoun HM, Betteridge DJ, Durrington PN, Hitman GA, et al. The safety and tolerability of atorvastatin $10 \mathrm{mg}$ in the Collaborative Atorvastatin Diabetes Study (CARDS). Diab Vasc Dis Res 2008;5:177-83.

26 SHARP Collaborative Group. Study of Heart and Renal Protection (SHARP): randomized trial to assess the effects of lowering low-density lipoprotein cholesterol among 9,438 patients with chronic kidney disease. Am Heart J 2010;160:785-94.e10.

27 Bone HG, Kiel DP, Lindsay RS, Lewiecki EM, Bolognese MA, Leary ET, et al. Effects of atorvastatin on bone in postmenopausal women with dyslipidemia: a double-blind, placebo-controlled, dose-ranging trial. J Clin Endocrinol Metab 2007;92:4671-7.

28 ClinicalTrials.gov. AURORA: crestor $10 \mathrm{mg}$ versus placebo in subjects with End-Stage Renal Disease (ESRD). NCT00240331. 2011. www.clinicaltrials.gov/ct2/show/ NCT00240331.

29 Fellstrom B, Holdaas H, Jardine AG, Rose H, Schmieder R, Wilpshaar W, et al. Effect of rosuvastatin on outcomes in chronic haemodialysis patients: baseline data from the AURORA study. Kidney Blood Press Res 2007;30:314-22.

30 Fellstrom B, Zannad F, Schmieder R, Holdaas H, Jardine A, Rose H, et al. Effect of rosuvastatin on outcomes in chronic haemodialysis patients-design and rationale of the AURORA study. Curr Control Trials Cardiovasc Med 2005;6:9.

31 ClinicalTrials.gov. Crestor versus placebo in subjects with heart failure. NCT00206310. 2011. www.clinicaltrials.gov/ct2/show/NCT00206310.

32 ClinicalTrials.gov. Lipitor in the prevention of stroke, for patients who have had a previous stroke (SPARCL). NCT00147602. 2011. www.clinicaltrials.gov/ct2/show/NCT00147602.

33 Amarenco P, Bogousslavsky J, Callahan AS, Goldstein L, Hennerici M, Sillsen H, et al. Design and baseline characteristics of the Stroke Prevention By Aggressive Reduction In Cholesterol Levels (SPARCL) study. Cerebrovasc Dis 2003;16:389-95.

34 ClinicalTrials.gov. GISSI-HF: effects of n-3 PUFA and rosuvastatin on mortality-morbidity of patients with symptomatic CHF. NCT00336336. 2011. www.clinicaltrials.gov/ct2/show/ NCT00336336.

35 Tavazzi L, Tognoni G, Franzosi MG, Latini R, Maggioni AP, Marchioli R, et al. Rationale and design of the GISSI heart failure trial: a large trial to assess the effects of $n-3$ polyunsaturated fatty acids and rosuvastatin in symptomatic congestive heart failure. Eur $J$ Heart Fail 2004;6:635-41.

36 Wanner C, Krane V, Ruf G, Marz W, Ritz E. Rationale and design of a trial improving outcome of type 2 diabetics on hemodialysis. Die Deutsche Diabetes Dialyse Studie Investigators. Kidney Int Suppl 1999;71:S222-6.

37 Wanner C, Krane V, Marz W, Olschewski M, Asmus HG, Kramer W, et al. Randomized controlled trial on the efficacy and safety of atorvastatin in patients with type 2 diabetes on hemodialysis (4D study): demographic and baseline characteristics. Kidney Blood Press Res 2004;27:259-66.

38 Holdaas H, Fellstrom B, Holme I, Nyberg G, Fauchald P, Jardine A, et al. Effects of fluvastatin on cardiac events in renal transplant patients: ALERT (Assessment of Lescol in Renal Transplantation) study design and baseline data. J Cardiovasc Risk 2001;8:63-71.

39 Holdaas H, Fellstrom B, Jardine AG, Holme I, Nyberg G, Fauchald P, et al. Effect of fluvastatin on cardiac outcomes in renal transplant recipients: a multicentre, randomised, placebo-controlled trial. Lancet 2003;361:2024-31.

40 Serruys PW, De Feyter PJ, Benghozi R, Hugenholtz PG, Lesaffre E. The Lescol(R) Intervention Prevention Study (LIPS): a double-blind, placebo-controlled, randomized trial of the long-term effects of fluvastatin after successful transcatheter therapy in patients with coronary heart disease. Int J Cardiovasc Intervent 2001;4:165-72.

41 Colhoun HM, Thomason MJ, Mackness MI, Maton SM, Betteridge DJ, Durrington PN, et al. Design of the Collaborative AtoRvastatin Diabetes Study (CARDS) in patients with type 2 diabetes. Diabet Med 2002;19:201-11.

42 Colhoun HM, Betteridge DJ, Durrington PN, Hitman GA, Neil HA, Livingstone SJ, et al. Primary prevention of cardiovascular disease with atorvastatin in type 2 diabetes in the Collaborative Atorvastatin Diabetes Study (CARDS): multicentre randomised placebo-controlled trial. Lancet 2004;364:685-96.

43 Tleyjeh IM, Kashour T, Hakim FA, Zimmerman VA, Erwin PJ, Sutton AJ, et al. Statins for the prevention and treatment of infections: a systematic review and meta-analysis. Arch Intern Med 2009;169:1658-67.

44 Myles PR, Hubbard RB, McKeever TM, Pogson Z, Smith CJ, Gibson JE. Risk of community-acquired pneumonia and the use of statins, ace inhibitors and gastric acid suppressants: a population-based case-control study. Pharmacoepidemiol Drug Saf 2009;18:269-75.

45 Becker K, Tanzi P, Kalil A, Shibata D, Cain K. Early statin use is associated with increased risk of infection after stroke. J Stroke Cerebrovasc Dis 2011; published online 20 Jul.

46 Thompson JN, Huycke MM, Greenfield RA, Kurdgelashvili G, Gentry CA. Case-control study of statin prevention of mould infections. Mycoses 2011;54:e481-5.

47 Toh S, Hernandez-Diaz S. Statins and fracture risk. A systematic review. Pharmacoepidemiol Drug Saf 2007;16:627-40.

48 Baigent C, Landray M, Leaper C, Altmann P, Armitage J, Baxter A, et al. First United Kingdom Heart and Renal Protection (UK-HARP-I) study: biochemical efficacy and safety of simvastatin and safety of low-dose aspirin in chronic kidney disease. Am J Kidney Dis 2005;45:473-84.

49 Colhoun HM, Betteridge DJ, Durrington PN, Hitman GA, Neil HA, Livingstone SJ, et al. Primary prevention of cardiovascular disease with atorvastatin in type 2 diabetes in the Collaborative Atorvastatin Diabetes Study (CARDS): multicentre randomised placebo-controlled trial. Lancet 2004;364:685-96. 


\section{What is already known on this topic}

Hydroxymethyl glutaryl coenzyme A reductase inhibitors, or statins, are widely used to prevent and treat cardiovascular disease Statins have diverse anti-inflammatory and immunomodulatory effects

Observational studies have reported a decreased risk of infections for people taking statins, but biased estimations in these studies cannot be ruled out

\section{What this study adds}

In this systematic review and meta-analysis of randomised placebo controlled trials, statins had no effect on the risk of infections The absence of any evidence towards a beneficial effect of statins on risk of infection in large placebo controlled trials potentially negates the causal effect reported in observational studies

50 Ridker PM, Danielson E, Fonseca FA, Genest J, Gotto AM Jr, Kastelein JJ, et al. Rosuvastatin to prevent vascular events in men and women with elevated C-reactive protein. N Engl J Med 2008;359:2195-207.

51 Hunt D, Young P, Simes J, Hague W, Mann S, Owensby D, et al. Benefits of pravastatin on cardiovascular events and mortality in older patients with coronary heart disease are equal to or exceed those seen in younger patients: results from the LIPID trial. Ann Intern Med 2001:134:931-40.

52 Shepherd J, Blauw GJ, Murphy MB, Bollen EL, Buckley BM, Cobbe SM, et al. Pravastatin in elderly individuals at risk of vascular disease (PROSPER): a randomised controlled trial. Lancet 2002;360:1623-30.

53 Cowell SJ, Newby DE, Prescott RJ, Bloomfield P, Reid J, Northridge DB, et al. A randomized trial of intensive lipid-lowering therapy in calcific aortic stenosis. $N$ Engl $J$ Med 2005;352:2389-97.

54 Sever PS, Dahlof B, Poulter NR, Wedel H, Beevers G, Caulfield M, et al. Prevention of coronary and stroke events with atorvastatin in hypertensive patients who have average or lower-than-average cholesterol concentrations, in the Anglo-Scandinavian Cardiac Outcomes Trial—Lipid Lowering Arm (ASCOT-LLA): a multicentre randomised controlled trial. Lancet 2003;361:1149-58.

55 Strandberg TE, Pyorala K, Cook TJ, Wilhelmsen L, Faergeman O, Thorgeirsson G, et al. Mortality and incidence of cancer during 10-year follow-up of the Scandinavian Simvastatin Survival Study (4S). Lancet 2004;364:771-7.

56 Sacks FM, Pfeffer MA, Moye LA, Rouleau JL, Rutherford JD, Cole TG, et al. The effect of pravastatin on coronary events after myocardial infarction in patients with average cholesterol levels. Cholesterol and Recurrent Events Trial investigators. N Engl J Med 1996:335:1001-9.

57 Fellstrom B, Abedini S, Holdaas H, Jardine AG, Staffler B, Gimpelewicz C, et al. No detrimental effect on renal function during long-term use of fluvastatin in renal transplant recipients in the Assessment of Lescol in Renal Transplantation (ALERT) study. Clin Transplant 2006;20:732-9.

58 Crouse JR 3rd, Raichlen JS, Riley WA, Evans GW, Palmer MK, O'Leary DH, et al. Effect of rosuvastatin on progression of carotid intima-media thickness in low-risk individuals with subclinical atherosclerosis: the METEOR Trial. JAMA 2007;297:1344-53.

59 Chan KL, Teo K, Dumesnil JG, Ni A, Tam J, ASTRONOMER Investigators. Effect of Lipid lowering with rosuvastatin on progression of aortic stenosis: results of the aortic stenosis progression observation: measuring effects of rosuvastatin (ASTRONOMER) trial. Circulation 2010;121:306-14.

Accepted: 3 October 2011

\section{Cite this as: BMJ 2011;343:d7281}

This is an open-access article distributed under the terms of the Creative Commons Attribution Non-commercial License, which permits use, distribution, and reproduction in any medium, provided the original work is properly cited, the use is non commercial and is otherwise in compliance with the license. See: http://creativecommons.org/licenses/by$\mathrm{nc} / 2.0 /$ and http://creativecommons.org/licenses/by-nc/2.0/legalcode. 


\section{Tables}

\begin{tabular}{|c|c|c|c|c|c|}
\hline Study & Details of participants & Primary outcome & Drug and daily dose (mg) & $\begin{array}{l}\text { Median } \\
\text { follow-up } \\
\text { (years) }\end{array}$ & $\begin{array}{l}\text { Mean age } \\
\text { (years) }\end{array}$ \\
\hline Fellstrom $2009^{18}$ & $\begin{array}{l}2773 \text { undergoing } \\
\text { haemodialysis }\end{array}$ & Time to major cardiovascular event & Rosuvastatin $10 \mathrm{mg} v$ placebo & 3.2 & 64 \\
\hline Kjekshus $2007^{19}$ & $\begin{array}{l}5011 \text { with coronary heart } \\
\text { disease }\end{array}$ & $\begin{array}{l}\text { Composite of cardiovascular event (fatal } \\
\text { or non-fatal) }\end{array}$ & Rosuvastatin $10 \mathrm{mg} v$ placebo & 2.7 & 73 \\
\hline Amerenco $2006^{20}$ & $\begin{array}{l}4731 \text { with previous stroke or } \\
\text { transient ischaemic attack }\end{array}$ & Time to non-fatal or fatal stroke & Atorvastatin $80 \mathrm{mg} v$ placebo & 4.9 & 63 \\
\hline GISSI-HF $2008^{21}$ & 4574 with chronic heart failure & $\begin{array}{l}\text { Time to death or admission for } \\
\text { cardiovascular event }\end{array}$ & Rosuvastatin $10 \mathrm{mg} v$ placebo & 3.9 & 68 \\
\hline Wanner $2005^{22}$ & $\begin{array}{l}1255 \text { with diabetes undergoing } \\
\text { haemodialysis }\end{array}$ & $\begin{array}{l}\text { Composite of cardiovascular events and } \\
\text { death from cardiac causes }\end{array}$ & Atorvastatin $20 \mathrm{mg} v$ placebo & 4 & 66 \\
\hline Stegmayr $2005^{17}$ & 143 with renal disease & $\begin{array}{l}\text { All cause mortality, myocardial } \\
\text { infarction, coronary artery bypass } \\
\text { surgery, percutaneous transluminal } \\
\text { coronary angioplasty }\end{array}$ & Atorvastatin $10 \mathrm{mg} v$ placebo & 2 & 68 \\
\hline $\begin{array}{l}\text { Holdaas (ALERT } \\
\left.\text { extension }^{*}\right) 2005^{23}\end{array}$ & 1652 after renal transplant & First major adverse cardiac event & Fluvastatin $40 \mathrm{mg} v$ placebo & 6.7 & 48 \\
\hline Serruys $2002^{24}$ & $\begin{array}{l}1677 \text { with chronic heart } \\
\text { disease }\end{array}$ & Time to major adverse cardiac event & Fluvastatin $80 \mathrm{mg} v$ placebo & 3.9 & 60 \\
\hline Newman $2008^{25}$ & 2838 with diabetes & Time to major adverse cardiac event & Atorvastatin $10 \mathrm{mg} v$ placebo & 3.9 & 62 \\
\hline $\begin{array}{l}\text { Study of Heart and } \\
\text { Renal Protectiont } \\
2010^{26}\end{array}$ & 5245 with renal disease & $\begin{array}{l}\text { Composite of major atherosclerotic } \\
\text { events (myocardial infarction, death } \\
\text { from coronary heart disease, stroke) }\end{array}$ & Simvastatin $20 \mathrm{mg} v$ placebo & 1 & 61 \\
\hline Bone $2007 \ddagger^{27}$ & 626 postmenopausal women & $\begin{array}{l}\text { Percentage change from baseline in } \\
\text { lumbar (L1-4) spine bone mineral } \\
\text { density }\end{array}$ & $\begin{array}{l}\text { Atorvastatin } 10-80 \mathrm{mg} v \\
\text { placebo }\end{array}$ & 1 & 59 \\
\hline
\end{tabular}

*Publication of two year extension of original study. ALERT trial had a follow-up of 5.1 years, which was included in average.

†After one year a re-randomisation followed and intervention changed. Study continued until four years' follow-up with intervention of placebo versus ezetimibe or simvastatin.

$\ddagger 118,121,124$, and 122 participants received atorvastatin $10 \mathrm{mg}, 20 \mathrm{mg}, 40 \mathrm{mg}$, and $80 \mathrm{mg}$, respectively. 


\begin{tabular}{|c|c|c|c|c|c|c|c|c|}
\hline \multirow[b]{2}{*}{ Study } & \multirow{2}{*}{$\begin{array}{l}\text { Sequence } \\
\text { generation }\end{array}$} & \multirow{2}{*}{$\begin{array}{l}\text { Allocation } \\
\text { concealment }\end{array}$} & \multirow[b]{2}{*}{ Adverse event monitoring } & \multirow{2}{*}{$\begin{array}{l}\text { Blinding of } \\
\text { participants } \\
\text { and staff }\end{array}$} & \multicolumn{2}{|c|}{ Withdrawal rate (\%) } & \multicolumn{2}{|c|}{$\begin{array}{l}\text { Loss to follow-up } \\
\text { (\%) }\end{array}$} \\
\hline & & & & & Statin & Placebo & Statin & Placebo \\
\hline $\begin{array}{l}\text { Fellstrom } \\
(\text { AURORA) }\end{array}$ & Randomised* & Unclear & $\begin{array}{l}\text { Assessment of safety and efficacy at three } \\
\text { and six months and every six months } \\
\text { thereafter until end of study }\end{array}$ & Double blinded & 29.1 & 29.5 & 0 & 0 \\
\hline $\begin{array}{l}\text { Kjekshus } \\
(\text { CORONA })^{1931}\end{array}$ & $\begin{array}{l}\text { Adequate, computer } \\
\text { random generation }\end{array}$ & Adequate & $\begin{array}{l}\text { Assessment of adverse events at six weeks } \\
\text { and three months and every three months } \\
\text { thereafter. Additional questionnaire on } \\
\text { muscle symptoms requested }\end{array}$ & Double blinded & 19.5 & 21.9 & NR & NR \\
\hline $\begin{array}{l}\text { Amarenco } \\
(\text { SPARCL) }\end{array}$ & Randomised* & Unclear & $\begin{array}{l}\text { Assessment of adverse events and blood } \\
\text { chemistry tests at } 1,3,6 \text {, and } 12 \text { months } \\
\text { and than every six months until end of trial }\end{array}$ & Double blinded & 3.3 & 4.4 & 0.63 & 0.42 \\
\hline GISSI-HF ${ }^{213435}$ & $\begin{array}{l}\text { Adequate, computer } \\
\text { random generation }\end{array}$ & Adequate & $\begin{array}{l}\text { Assessment of serious adverse events } \\
\text { (defined as fatal, life threatening, requiring } \\
\text { or prolonging hospital stay, permanently } \\
\text { disabling or incapacitating, which may } \\
\text { jeopardise participant or which may require } \\
\text { medical or surgical intervention) related } \\
\text { and not related to study drugs }\end{array}$ & Double blinded & 1.1 & 1.3 & 0.13 & 0.04 \\
\hline $\begin{array}{l}\text { Wanner }(4 \mathrm{D})^{2236} \\
37\end{array}$ & $\begin{array}{l}\text { Adequate, computer } \\
\text { random generation }\end{array}$ & Adequate & $\begin{array}{l}\text { Assessment of serious adverse events } \\
\text { continuously, and data recording at four } \\
\text { weeks and then every six months }\end{array}$ & Double blinded & 22.9 & 23.6 & 0 & 0.16 \\
\hline Stegmayr ${ }^{17}$ & $\begin{array}{l}\text { Adequate, computer } \\
\text { random generation }\end{array}$ & Adequate & $\begin{array}{l}\text { Adverse events and liver tests monitored } \\
\text { at } 1,3,6,12,18,24,30 \text {, and } 36 \text { months of } \\
\text { follow-up }\end{array}$ & Not blinded & 28.6 & 8.2 & 1.4 & 0 \\
\hline $\begin{array}{l}\text { Holdaas (ALERT } \\
\text { extension†) }\end{array}$ & $\begin{array}{l}\text { Adequate, computer } \\
\text { random generation }\end{array}$ & Adequate & $\begin{array}{l}\text { Assessment of clinically and laboratory } \\
\text { adverse events, at six weeks and every six } \\
\text { months thereafter }\end{array}$ & Double blinded & 1.5 & 0.95 & 0.29 & 0.38 \\
\hline Serruys ${ }^{2440}$ & Adequate & $\begin{array}{l}\text { Adequate, } \\
\text { central } \\
\text { allocation }\end{array}$ & $\begin{array}{l}\text { Assessment of adverse events at six weeks } \\
\text { and every six months thereafter }\end{array}$ & Double blinded & 34.6 & 44.2 & 0.83 & 1.20 \\
\hline $\begin{array}{l}\text { Newman, } \\
(\text { CARDS) })^{254142}\end{array}$ & $\begin{array}{l}\text { Adequate, computer } \\
\text { random generation }\end{array}$ & Adequate & $\begin{array}{l}\text { Assessment of adverse events monthly for } \\
\text { first three months, then at six months, and } \\
\text { thereafter every six months }\end{array}$ & Double blinded & NR & NR & 0.56 & 1.13 \\
\hline $\begin{array}{l}\text { Study of Heart } \\
\text { and Renal } \\
\text { Protection }\end{array}$ & Randomised* & Unclear & $\begin{array}{l}\text { Assessment of early adverse effects at two } \\
\text { and six months and every six months } \\
\text { thereafter }\end{array}$ & Double blinded & NR & NR & NR & NR \\
\hline Bone $^{27}$ & $\begin{array}{l}\text { Adequate, computer } \\
\text { random generation }\end{array}$ & Adequate & $\begin{array}{l}\text { Assessment of adverse events at } \\
\text { occurrence }\end{array}$ & Double blinded & 27.6 & 27.7 & NR & NR \\
\hline
\end{tabular}

$\mathrm{NR}=$ not reported.

${ }^{\star}$ Exact method not described.

†Publication of two year extension of original study. 


\begin{tabular}{|c|c|c|c|c|c|c|c|}
\hline \multirow[b]{2}{*}{ Study source } & \multicolumn{3}{|c|}{ Infection related adverse events } & \multicolumn{3}{|c|}{ Infection related mortality } & \multirow[b]{2}{*}{ Source of data } \\
\hline & $\begin{array}{c}\text { No of events in } \\
\text { intervention } \\
\text { group }\end{array}$ & $\begin{array}{l}\text { No of events in } \\
\text { placebo group }\end{array}$ & Type of infection & $\begin{array}{l}\text { No of events in } \\
\text { intervention } \\
\text { group }\end{array}$ & $\begin{array}{l}\text { No of events in } \\
\text { placebo group }\end{array}$ & Type of infection & \\
\hline Fellstrom $^{18}$ & 976 & 956 & $\begin{array}{l}\text { Bronchitis, pneumonia, } \\
\text { nasopharyngitis, and } \\
\text { urinary tract infections }\end{array}$ & 105 & 100 & NR & Published \\
\hline Kjekshus $^{19}$ & 344 & 370 & NR & 54 & 68 & NR & Published \\
\hline Amarenco $^{20}$ & 414 & 439 & NR & 26 & 20 & NR & Published \\
\hline GISSI-HF $^{21}$ & 191 & 160 & $\begin{array}{l}\text { Respiratory tract } \\
\text { infections, urinary tract } \\
\text { infections, sepsis, } \\
\text { hepatobiliary infections, } \\
\text { and other infections }\end{array}$ & 21 & 14 & $\begin{array}{l}\text { Respiratory tract } \\
\text { infections, sepsis, } \\
\text { and other } \\
\text { infections }\end{array}$ & $\begin{array}{l}\text { Published as well } \\
\text { as provided by } \\
\text { authors }\end{array}$ \\
\hline Wanner $^{22}$ & NR & NR & NR & 60 & 68 & NR & Published \\
\hline Stegmayr ${ }^{17}$ & NR & NR & NR & 4 & 7 & NR & Published \\
\hline $\begin{array}{l}\text { Holdaas (ALERT } \\
\left.\text { extension }{ }^{\star}\right)^{23}\end{array}$ & NR & NR & NR & 34 & 35 & NR & Published \\
\hline Serruys ${ }^{24}$ & NR & NR & NR & 1 & 3 & Sepsis & Published \\
\hline Newman $^{25}$ & 8 & 9 & NR & NR & NR & NR & Published \\
\hline $\begin{array}{l}\text { Study of Heart and } \\
\text { Renal Protection }{ }^{26}\end{array}$ & 1 & 6 & Infective hepatitis & NR & NR & NR & Published \\
\hline Bone $^{27}$ & $129 \ddagger$ & 32 & $\begin{array}{l}\text { Respiratory tract infections } \\
\text { and urinary tract infections }\end{array}$ & NR & NR & NR & Published \\
\hline
\end{tabular}

\section{NR=not reported.}

${ }^{*}$ Causes of death by original treatment group after open label extension, in which all participants were offered fluvastatin treatment, based on intention to treat population.

†Study group receiving intervention (statin) was four times as large as placebo group.

$\ddagger$ Total of $25,25,41$, and 38 participants experienced infections in groups receiving atorvastatin $10 \mathrm{mg}, 20 \mathrm{mg}, 40 \mathrm{mg}$, and $80 \mathrm{mg}$, respectively. 


\section{Figures}

\begin{tabular}{|c|c|c|c|}
\hline \multicolumn{2}{|c|}{$\begin{array}{l}\text { Potentially relevant articles identified and screened } \\
\text { for retrieval through database searching }(n=607)\end{array}$} & \multicolumn{2}{|c|}{$\begin{array}{l}\text { Potentially relevant articles identified and screened } \\
\text { for retrieval through hand searching }(n=25)\end{array}$} \\
\hline \multicolumn{4}{|c|}{ trat } \\
\hline \multicolumn{4}{|c|}{ Articles after duplicates removed $(n=587)$} \\
\hline & & \multicolumn{2}{|c|}{$\begin{array}{l}\text { Articles excluded, based on title and abstract }(n=452) \text { : } \\
\text { Follow up }<12 \text { months }(n=302) \\
\text { Not placebo controlled }(n=46) \\
\text { Intervention was no statin }(n=40) \\
\text { Rationale, study protocol, or baseline report }(n=21) \\
\text { Subgroup analysis of included, duplicate, or excluded trials } \\
(n=18) \\
\text { Intervention combined with other treatment }(n=10) \\
\text { Not randomised clinical trial }(n=7) \\
\text { Review }(n=5) \\
\text { Outcome of no interest }(n=3)\end{array}$} \\
\hline \multicolumn{4}{|c|}{ Articles retrieved in full text for detailed evaluation $(n=135)$} \\
\hline & & \multicolumn{2}{|c|}{$\begin{array}{l}\text { Articles excluded, based on full text }(n=97) \text { : } \\
\text { No adverse events mentioned }(n=66) \\
\text { Follow up } 12 \text { months }(n=26) \\
\text { Not placebo controlled }(n=2) \\
\text { Subgroup analysis of included, duplicate, or excluded trials } \\
(n=2) \\
\text { No full text available }(n=1)\end{array}$} \\
\hline \multicolumn{4}{|c|}{ Articles with data on incidence of adverse events and mortality $(n=38)$} \\
\hline$\sqrt{ }$ & & & $\eta$ \\
\hline \multirow{2}{*}{$\begin{array}{l}\text { Articles excluded: subgroup analysis of } \\
\text { included, duplicate, or excluded trials; } \\
\text { adverse events not specified; } \\
\text { no infections mentioned }(n=15)\end{array}$} & \multicolumn{2}{|c|}{$\begin{array}{l}\text { Articles reported infections as adverse } \\
\text { event or cause of death }(n=10)\end{array}$} & $\begin{array}{l}\text { Potentially relevant articles and } \\
\text { authors contacted for primary and } \\
\text { supplementary information }(n=13)\end{array}$ \\
\hline & & & \\
\hline & & $\downarrow$ & $\downarrow$ \\
\hline & \multicolumn{2}{|c|}{ Articles included in meta-analysis $(n=11)$} & $\begin{array}{l}\text { Articles excluded: no data available; } \\
\text { data not provided }(n=12)\end{array}$ \\
\hline
\end{tabular}

Fig 1 Flow of participants through review

\begin{tabular}{|c|c|c|c|c|c|c|c|}
\hline \multirow{3}{*}{ Study } & \multicolumn{7}{|c|}{ No of events/No of participants } \\
\hline & \multirow{2}{*}{$\begin{array}{l}\text { Statin } \\
1 / 1054\end{array}$} & \multirow{2}{*}{$\begin{array}{l}\text { Placebo } \\
6 / 4191\end{array}$} & & & $\begin{array}{c}\text { Relative risk } \\
(95 \% \mathrm{Cl})\end{array}$ & $\begin{array}{l}\text { Weight } \\
\text { (\%) }\end{array}$ & \multirow{2}{*}{$\begin{array}{c}\begin{array}{c}\text { Relative risk } \\
(\mathbf{9 5 \%} \mathrm{Cl})\end{array} \\
0.66(0.08 \text { to } 5.50)\end{array}$} \\
\hline & & & & & & 0 & \\
\hline Fellstrom $2009^{18}$ & $976 / 1389$ & $956 / 1378$ & & & $\phi$ & 72.7 & 1.01 (0.96 to 1.06$)$ \\
\hline Newman $2008^{25}$ & $8 / 1428$ & $9 / 1410$ & & & 1 & 0.2 & $0.88(0.34$ to 2.27$)$ \\
\hline GISSI-heart failure $2008^{21}$ & $191 / 2285$ & $160 / 2289$ & & & - & 4.3 & $1.20(0.98$ to 1.46$)$ \\
\hline Kjekshus $2007^{19}$ & $344 / 2514$ & $370 / 2497$ & & & - & 9.4 & $0.92(0.81$ to 1.06$)$ \\
\hline Bone $2007^{27}$ & $129 / 485$ & $32 / 119$ & & & + & 1.6 & $0.99(0.71$ to 1.38$)$ \\
\hline Amarenco $2006^{20}$ & $414 / 2365$ & $439 / 2366$ & & & - & 11.8 & $0.94(0.84$ to 1.07$)$ \\
\hline Random effects total $(P=0.927)$ & $2063 / 11520$ & $1972 / 14250$ & & & 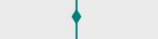 & 100.0 & $1.00(0.96$ to 1.05$)$ \\
\hline \multirow{2}{*}{\multicolumn{2}{|c|}{ Test for heterogeneity: $\chi^{2}=5.69, \mathrm{df}=6, \mathrm{P}=0.46, \mathrm{I}^{2}=5.46 \%$}} & & 0.01 & 0.1 & 1 & 10 & \\
\hline & & & $\begin{array}{l}\text { Favours } \\
\text { treatment }\end{array}$ & & & $\begin{array}{l}\text { urs } \\
\text { trol }\end{array}$ & \\
\hline
\end{tabular}

Fig 2 Meta-analysis of statin treatment and risk of infections in randomised controlled trials 


\section{Study}

$\begin{array}{lcc}\text { Fellstrom 2009 } & 105 / 1389 & 100 / 1378 \\ \text { GISSI-heart failure } 2008^{21} & 21 / 2285 & 14 / 2289 \\ \text { Kjekshus } 2007^{19} & 54 / 2514 & 68 / 2497 \\ \text { Amarenco } 2006^{20} & 26 / 2365 & 20 / 2366 \\ \text { Wanner 2005 } & \\ \text { Stegmayr } 2005^{17} & 60 / 619 & 68 / 636 \\ \text { Holdaas } 2005^{23} & 4 / 70 & 7 / 73 \\ \text { Serruys 2002 } & 34 / 1050 & 35 / 1052 \\ \text { Random effects total }(P=0.705) & 1 / 844 & 3 / 833 \\ \text { Test for heterogeneity: } \chi^{2}=5.89, \mathrm{df}=7, P=0.55,\left.\right|^{2}=18.76 \% & \end{array}$

No of events/No of participants

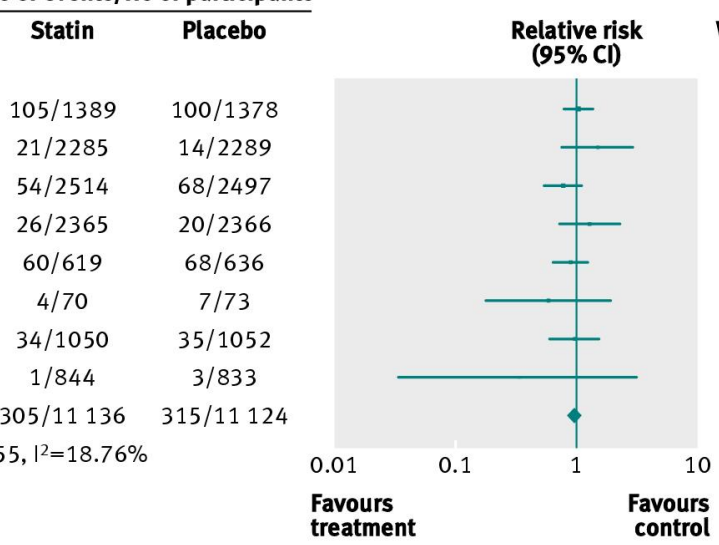

Fig 3 Meta-analysis of statins and risk of infection related mortality in randomised controlled trials 